\title{
Protective Effect of Aloe Vera Gel in Ulcerative Colitis: The Role of Inflammatory and Anti-Inflammatory Factors
}

Zakieh Keshavarzi ${ }^{1}$, Mosa-Al- Reza Hadjzadeh ${ }^{2}$, Masoud Nazari ${ }^{3}$, Roghaye Arezumand ${ }^{4}$

1.Associated Professor of Natural Products and Medicinal Plants Research Center, North Khorasan University of Medical Sciences, Bojnurd, Iran., (Corresponding Author), Tel: 058-31513007, E-mail: Zakieh_keshavarzi@ yahoo.com , ORCID ID: 0000-0001-5992-1291

2.Professor of Neurocognitive Research Center, College of Medicine, Mashhad University of Medical Sciences, Mashhad, Iran. ORCID ID: 0000-0003-0086-6472

3.Assistant Professor of Natural Products and Medicinal Plants Research Center, North Khorasan University of Medical Sciences, Bojnurd, Iran. ORCID ID: 0000-0002-8138-4151

4.Assistant Professor of Natural Products and Medicinal Plants Research Center, North Khorasan University of Medical

Sciences, Bojnurd, Iran. ORCID ID: 0000-0003-4197-2490

\begin{abstract}
Aim and Background: Anti-inflammatory compounds are effective in improving the symptoms of inflammatory bowel diseases such as ulcerative colitis. The aim of this study was to evaluate the effect of aloe vera extract against the inflammatory factors affecting acetic acid-induced ulcerative colitis.
\end{abstract}

Materials and Methods: 32 male Wistar rats are divided into 4 groups of 8 including: control group, untreated colitis group, colitis group treated with aloe vera ( $200 \mathrm{mg} / \mathrm{kg} / \mathrm{day}$ ) and sulfasalazine group as a standard treatment $(500 \mathrm{mg} / \mathrm{kg} /$ day) from two days before induction of colitis to 5 days after induction of colitis. Experimental colitis was induced by intrarectal injection of $2 \mathrm{ml}$ of $3 \%$ acetic acid. Rats were sacrificed on the eighth day of induction of colitis and some factors involved in inflammation, such as tumor necrosis factoralpha, interleukin-10, cyclooxygenase 2 (COX II) and PGE2 levels in colon tissue were measured.

Results: Inflammation induced in colon by acetic acid injection. Sulfasalazine and aloe vera reduced the inflammatory factor (tumor necrosis factor alpha) and increased antiinflammatory factor (interleukin-10) in colon tissue. But they had no effect on the COX II and PGE2 levels in colon tissue.

Conclusion: The results suggested that aloe vera could possibly improve colitis by suppressing inflammatory promoting factors and increasing anti-inflammatory factors.

Keywords: Sulfasalazine, COX II, PGE2, Tumor necrosis factor alpha, Interleukin 10

Received: Nov 28, $2020 \quad$ Accepted: June 30, 2021

How to cite the article: Zakieh Keshavarzi, Mosa-Al- Reza Hadjzadeh, Masoud Nazari, Roghaye Arezumand. Protective effect of aloe vera gel in ulcerative colitis: the role of inflammatory and antiinflammatory factors. SJKU 2019;26(4):69-79.

Copyright (C) 2018 the Author (s). Published by Kurdistan University of Medical Sciences. This is an open access article distributed under the terms of the Creative Commons Attribution-Non Commercial License 4.0 (CCBYNC), where it is permissible to download, share, remix, transform, and buildup the work provided it is properly cited. The work cannot be used commercially without permission from the journal 


\section{اثر محافظتى ذل آلوئه ورا بر كوليت اولسراتيو: نقش فاكتور رهاى التهابى و ضدالتهابى

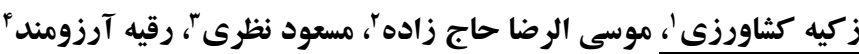

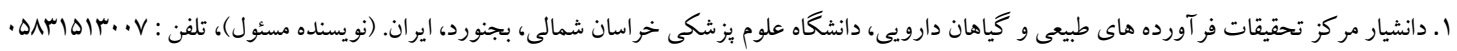

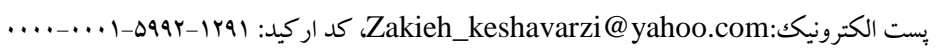

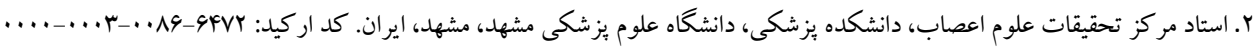

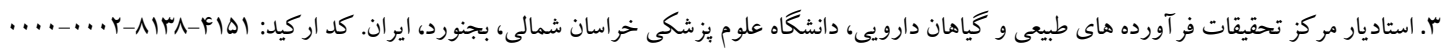

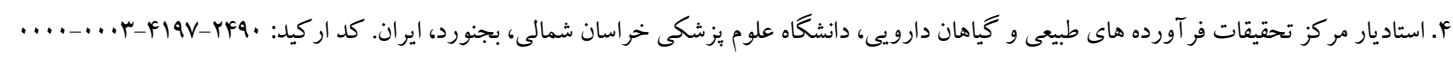

زمينه و هدف: تركيبات ضد التهابى در بهبود علائم بيمارى هاى التهابى روده مانند كوليت اولسراتيو موثرند. آلوئه ورا نقش مهمى در كاهش فاكتورهاى التهابى دارد. بنابر اين هدف از اين مطالعه بررسى اثر آلوئه ورا بر فاكتورهاى التهابى موثر در كوليت

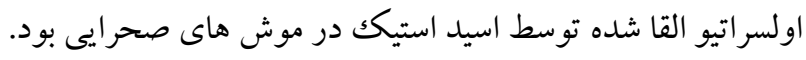

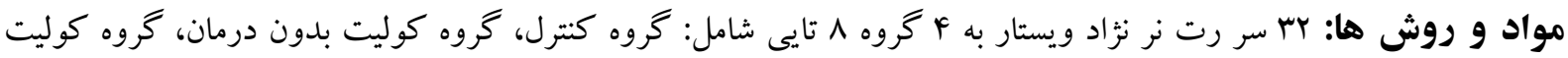

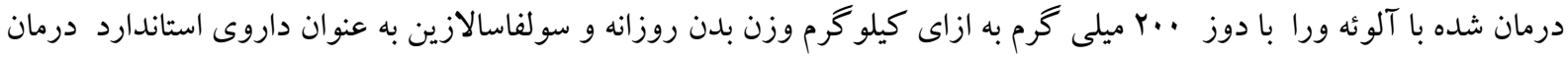

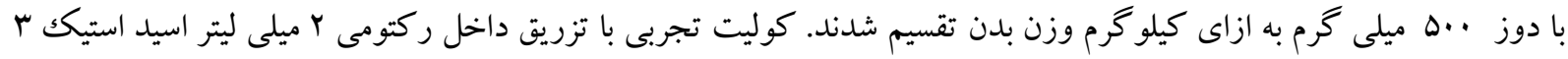

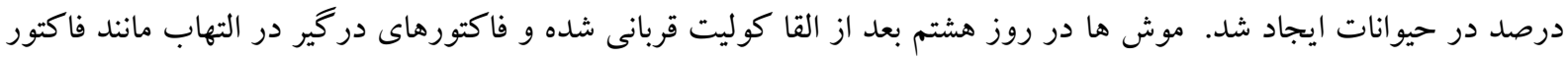

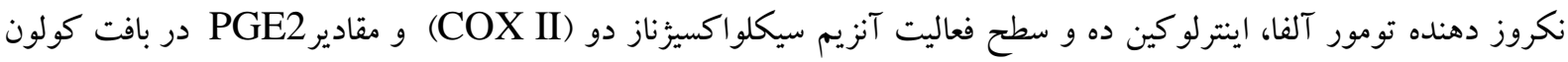
اندازه كيرى شد. يافته ها: تزريق اسيد استيكك موجب التهاب كولون گرديد. سولفاسالازين و آلوئه ورا باعث كاهش فاكتور التهابى فاكتور نكروز دهنده تومور آلفاو افزايش فاكتور ضد التهابى اينترلو كين ده در بافت كولون شد. وليكن اثرى بر مقادير COX II و و بافت كولون نداشت. نتيجه كيرى: اين نتايج ييشنهاد مى كند كه آلوئه ورا احتمالا مى تو اند از طريق سر كوب فاكتورهاى بيش برنده التهاب و افزايش فاكتورهاى ضد التهابى در بهبود كوليت موثر باشد.

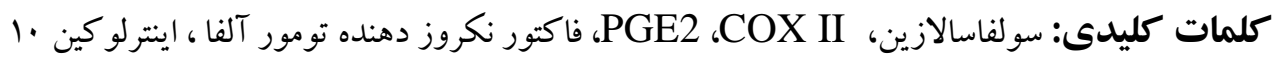

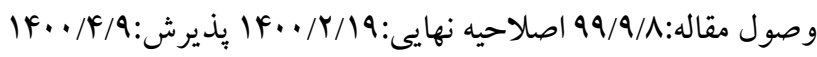


وسيله اسيد استيك بيشترين شباهت را با كوليت در انسان است (†, ه)، بنابراين در مطالعه حاضر از اين مدل براى

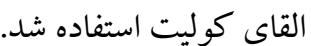
از جمله روش هاى درمانى بيمارىهاى التهابى روده مى

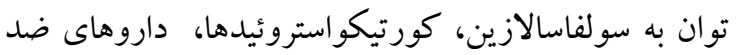
التهابى، آنتى بيوتيك،، داروهاى ضد فاكتور نكروز دهنده

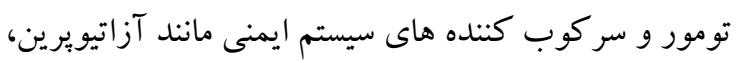

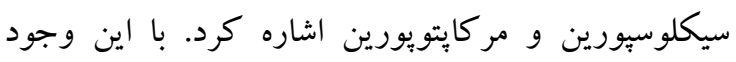

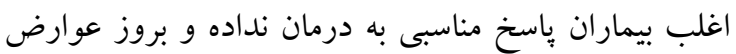
جانبى دارو نيز منجر به محدوديت درمان مى شود. استفاده از گياهان دارويى قدمت طولانى داشته و امروزه استفاده از

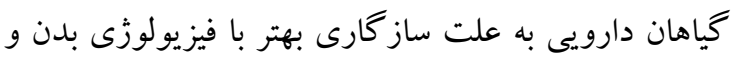

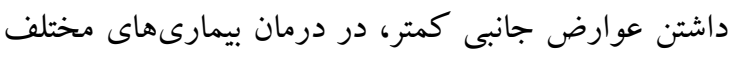
رو به افزايش است (9). مطالعات بسيارى در زمينه گياهان دارويى در درمان و بهبود علائم كوليت اولسراتيو ييشنهاد

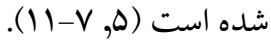

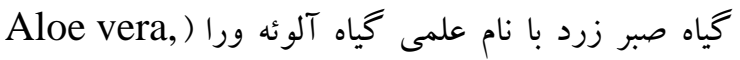

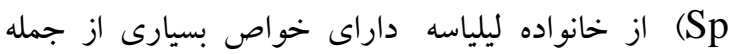
خاصيت ضدويروسى، ضد قارجى، ضد باكتريايى، ضد روماتيسمى، ضد سرطانى، ضد ويرى يوست، ضد عفونى

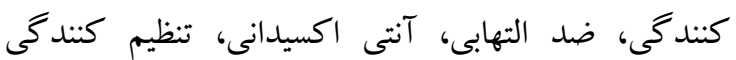
سيستم ايمنى، بهبود دهنده جراحت ها و آسيب ها هستند

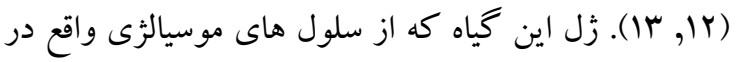
ناحيه مركزى برگك هاى آن توليد مى شود، داراى مولكول ها و اجزاى فعال زيستى است كه بر فعاليت فيبروبلاست ها، افزايش توليد كلازن و تحريكك و شكل گيرى بافت إيدرم موثر است (f) (1) أنشان داده شده است كه عصاره آلوئه ورا مى تواند براى درمان بيمارى هايى جون مشكلات معده است دهان ایىروده اى، دردهاى مزمن، بيمارى هاى يوستى، التهاب،

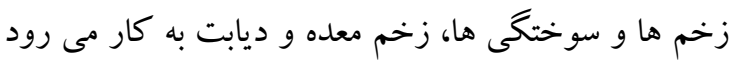

اعتقاد بـر ايـن اسـت كـه بيـان بـيش از حـد ميـانجى هـاى

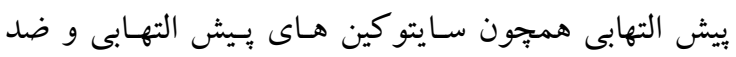

مقدمه يكى از انواع بيمارى هاى التهابى روده، كوليت اولسراتيو يا كوليت زخمى مى باشد كه ناشى از التهاب مزمن سلول هاى

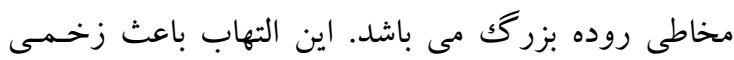

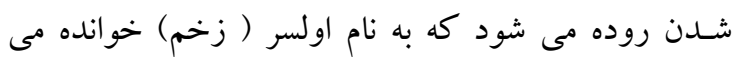

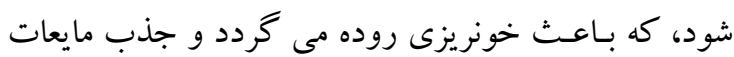
از روده بزر گك مختل مى شود (1).

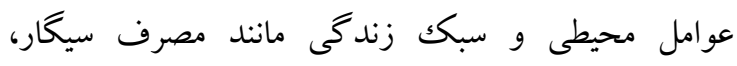
استرس، دارو و تغذيه نامناسب با بروز بيمارى هاى التهابى روده مرتبط اند. بيمارى هاى التهابى روده به وسيله جند

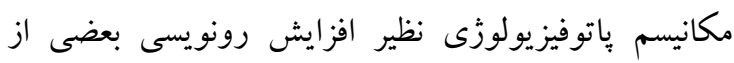

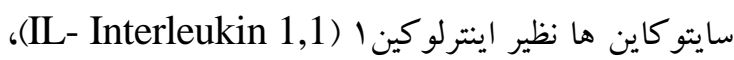
اينترلو كين 4 (Interleukin 6, IL-6) و فاكتور نكروز دهنده تومور آلفا ( Tumor necrosis factor, TNF a اسهال، وجود خون در مدفوع و كاهش وزن دارد(Y).

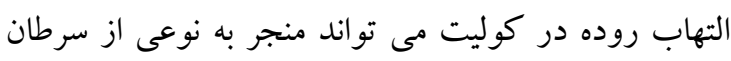

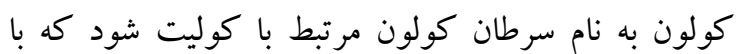

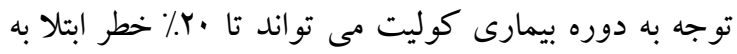
سرطان كولور كتال را افزايش دهد. سرطان كولور كتال، باعث تخريب بيشتر روده بزرگك مى شود و طول عمر بيماران را كاهش مى دهد (r). مدل هاى مختلفى از كوليت به عنوان يكك ابزار ضرورى ينال براى كشف مكانيزم هاى بيمارىزايى بيمارى التهابى روده براى تعيين درمان هاى بالقوه توسعه يافته كه شامل اسيد استيك، دكستران سولفات سديم ( dextran sodium sulfate, DSS بنزن سولفونيك اسيد (2,4,6-Trinitrobenzene (sulfonic acid, TNBS التهابى روده بيمارى مزمن جندعاملى است و در امور

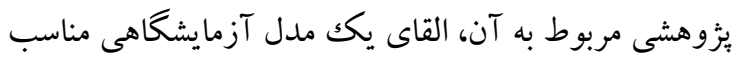
كه بيشترين شباهت را به سير بالينى بيمارى در انسان داشته بروبه باشد، امرى ضرورى محسوب مىشود، كوليت ايجادشده به 
مقادير فاكتور نكروز دهنده تومور آلفا، اينترلوكين ده و

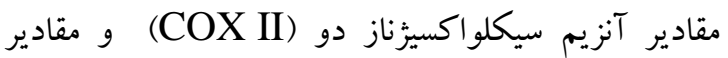
در بافت كولون در ^روز بعد از القاى كوليت PGE2

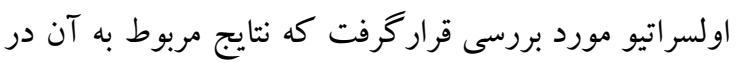

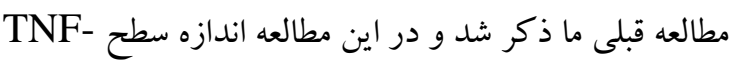

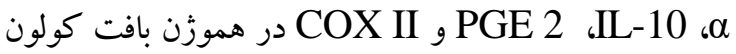
اندازه گيرى شد. گروه هاى تحت مطالعه شامل موارد زير

1- گروه سالم (Intact): موش هاى دست نخورده ب

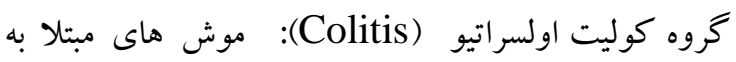

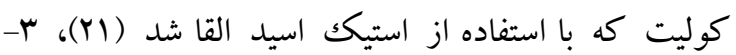
كروه درمان با آلوئه ورا (Aloe Vera)، موش هاى مبتهل

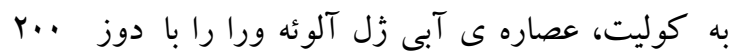

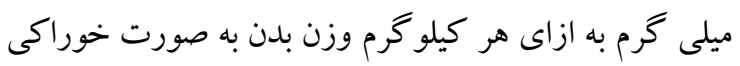
به مدت ^روز از طريق خوراكى دريافت كردند (YY)، F-

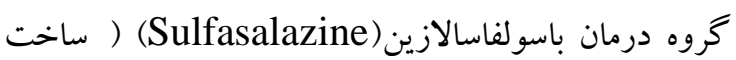
شركت كارن، قرص .ه ميلى گرمى) به عنوان درمان

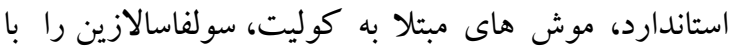

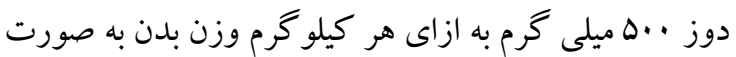

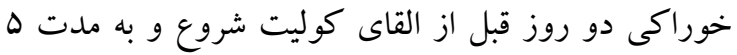
روز بعد از القاى كوليت دريافت كردند (بr). روش تهيه عى عصاره ى زل آلوئه ورا :

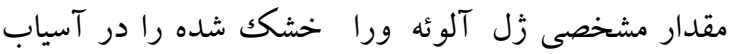
برقى ريخته تا يودر شود .يودر خشك شده را به مدت حداكثر 48 ساعت خيسانده و در آب حل كرده و در طى اين مدت جندين بار ظرف تكان داده شده تا آب به راحتى تبخير شود .بعد آن را صاف كرده و عصاره آبى بدست آمده را در لوله آزمايش ريخته و در دستگاه سانتريفيوز با سرعت بOYY دور بر دقيقه به مدت 1 دقيقه قرار داده تا ذرات معلق در آن جدا شود .بعد از سانتريفيوز مايع بدست آمده را در آون و در دماى سانتى گراد قرار داده تا شيره غليظى باقى بماند .رسوبات خشك شده را وزن نموده تا وزن مقدار ماده حل نشده
التهابى نقش اساسـى در كوليت اولسراتيو دارنســـــ از ايـن ميـان TNF- مهـمتـرين سايتوكاين يش التهابى شناخته شده است. $\alpha$ TNF- باعث القاء توليد كونه هاى

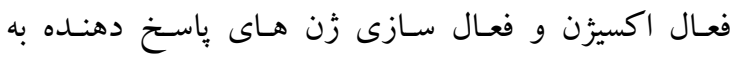

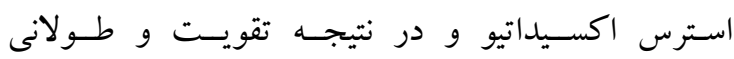
كــردن التهـاب مى شـود (1) (1). IL-10 ،يكك سايتو كاين جندعملكردى مهم است كه نقش كليدى در پياسخ التهابى

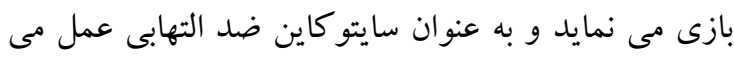

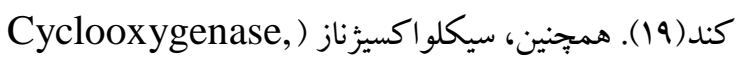
آنزيمى كليدى در تبديل اسيد آراشيدونيك به به (COX

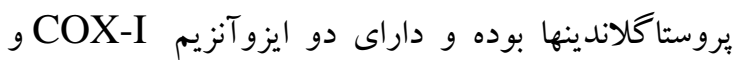
COX-II

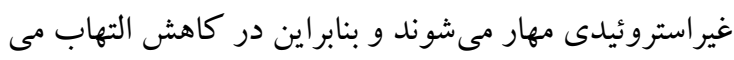
تو انند موثر باشند (r) (r). با توجه به مطالعات متعددى كه درارتباط با اثرات مفيد

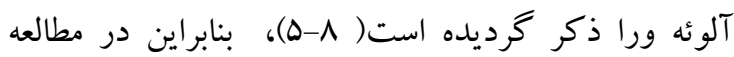
حاضر به بررسى نقش سايتوكاين هاى درگير در روند

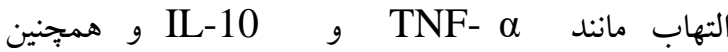

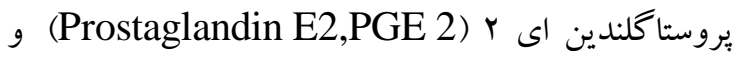
آنزيم COX II در مدل كوليت اولسراتيو القا شده با اسيد استيك در موش صحرايى و اثر زل آلوئه ورا بر اين سايتو كاين ها يرداختيم.

\section{مواد و روش ها}

در اين مطالعه از بr سر موش صحر ايى نر نزاد ويستار با

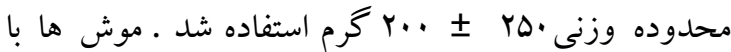
رعايت قوانين نخهدارى حيوانات آزمايشگاهى دانشكده

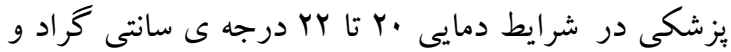
دوره ى روشنايى - تاريكى r ا ساعته نغهدارى مى شدند و دسترسى آزادنه به آب و غذا داشتند. با استفاده از مقالات مشابه حجم نمونه محاسبه گرديد (ه) و باين اساس، حيوانات به طور تصادفى به جهار گروه كه هر گروه شامل ^ سر موش صحرايى است، تقسيم شدند و در هر گروهاه 
اندازه گيرى فاكتور ييش التهابى TNF-

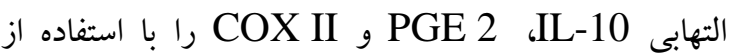
كيت هاى الايزا و بر اساس دستورالعمل شركت سازنده مورد بررسى قرار گرفت. (eBioscience) تجزيه و تحليل داده ها: داده ها به صورت ميانگين 土ـ انحراف معيار بيان شد . تجزيه

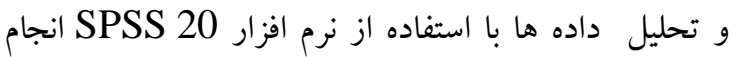

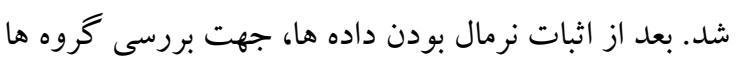

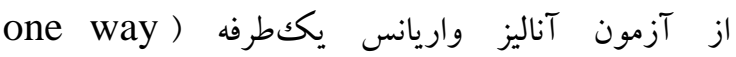
(ANOVA و تست تعقيب Tukey ) استفاده شد. تفاوتها

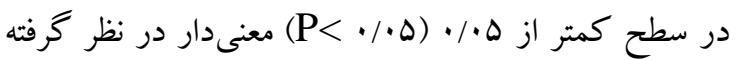

\section{يافته ها}

تغييرات سطح فاكتور نكروز دهنده تومور آلفا (TNFغلظت TNF- $\alpha$ در گروه سالم 19N/90 بود كه

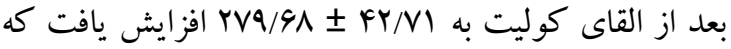

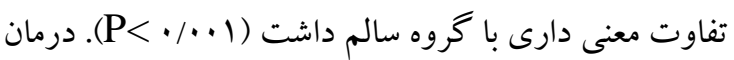
با عصاره ى آبى آلوئه ورا ميزان TNF-

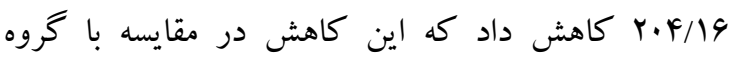

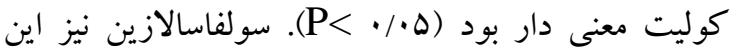

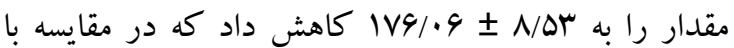
كروه كوليت معنى دار بود (1 P> P<). (نمودار 1).
بدست آيد و با كم نمودن از مقدار اوليه وزن ماده حل

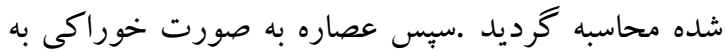

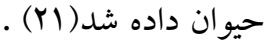
روش القاى كوليت اولسراتيو حاد :

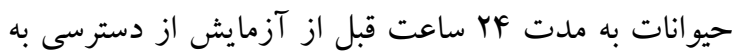
غذا محروم شدند. سبس هر حيوان بس از بيهوشى با اتر در

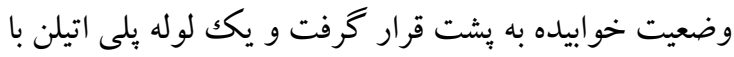
قطر خارجى Y ميلى متر را تا ^ سانتى متر از طريق ركتوم

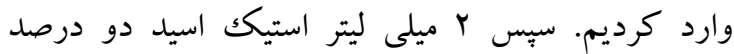

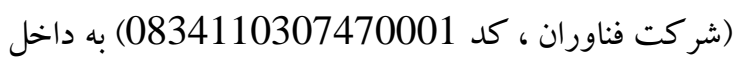

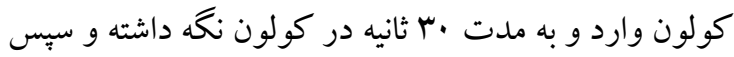
اجازه خروج داده شد. در روز هشتم تيمار، حيوانات قربانى و سبس كولون خارج شده و قسمت ابتدايى براى بررسى

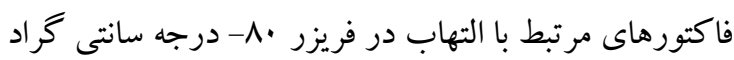

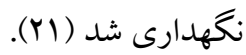

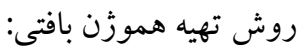

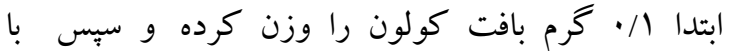
بافرفسفات (pH=V/F) با دستگاه هموزنايزر، هموزن كرديم. سيس بافت هموزن شده را با دور •ا1 به مدت ه دقيقه سانترفيوز كرديم. سبس مايع رويى را براى اندازه گيرى بهى

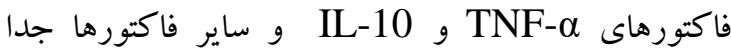
كرديم.

روش اندازه گيرى فاكتورهاى TNF:COX II , 2

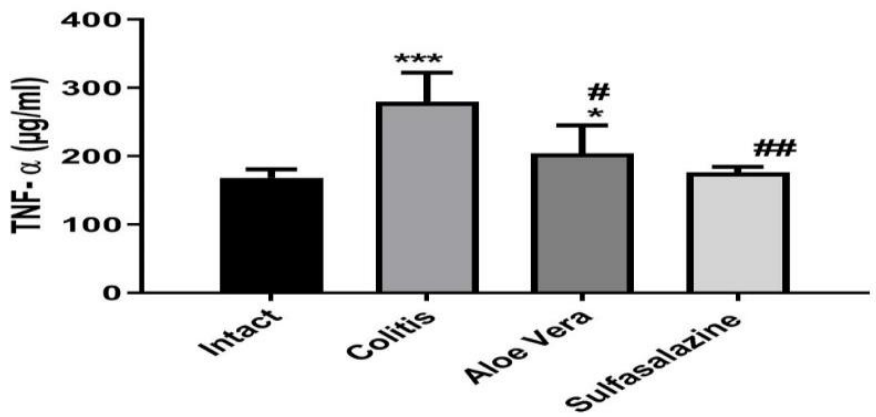

نمودار ا: تغيير ات غلظت TNF-a بافتى در كروه هاى مختلف كنترل، كوليت القا شده با اسيد استيك، درمان با آلوئه ورا، درمان با

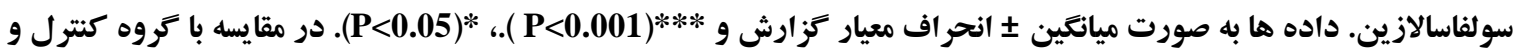

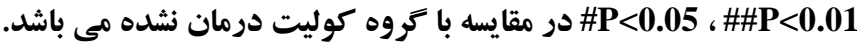

هبلم علمى دانشكاه علوه بِزشكى كردستان / دوره بيست و شش / دعر و آبان م.ع|| 


كوليت معنى دار بود ( (P> P (P). سولفاسالازين نيز اين

مقدار را به 1N/Fq كروه كوليت معنى دار بود ( ( + P> P). (نمودار Y).
تغييرات سطح فاكتور اينترلو كين · 1 (IL-10) :

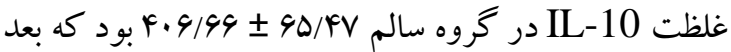

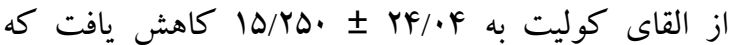

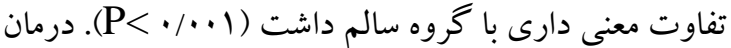
با عصاره ى آبى آلوئه ورا ميزان IL-10 را به وس/Yr

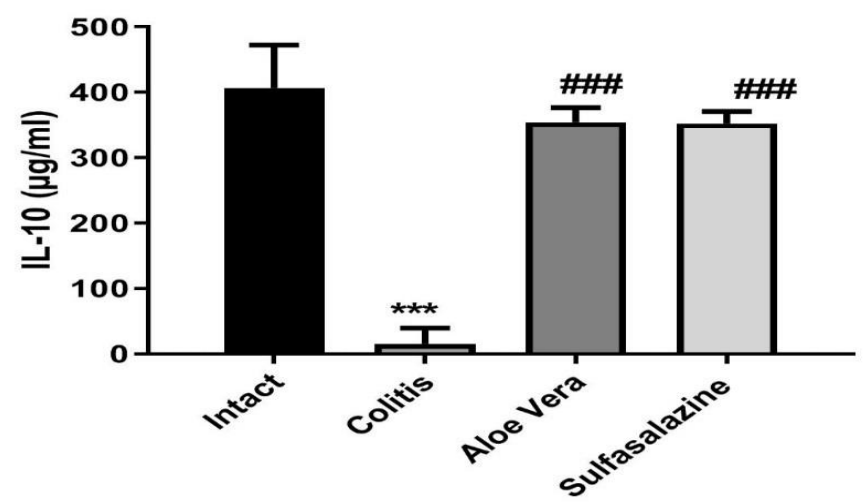

نمودار r: تغييرات غلظت IL-10 بافتى دركروه هاى مختلف كنترل، كوليت القا شده با اسيد استيك، درمان با آلوئه ورا، درمان با

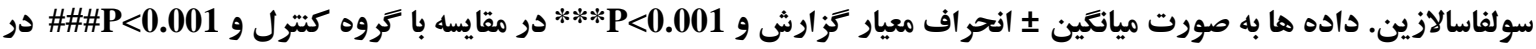
مقايسه با كروه كوليت درمان نشده معى باشد.

آلوئه ورا ميزان PGE 2 را به V PF

كه اين كاهش نيز در مقايسه با گروه كوليت معنى دار نبود.

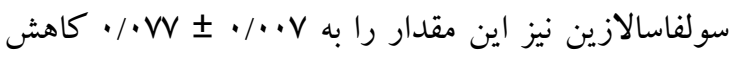

داد كه در مقايسه با كروه كوليت معنى دار نبود (نمودار ب).
تغييرات سطح بروستا گلندين PGE 2) E2):

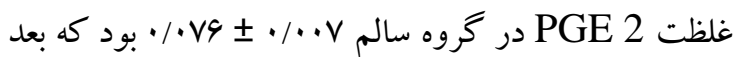

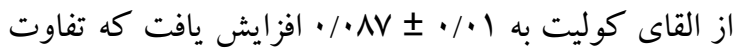
معنى دارى با گروه سالم نداشت. درمان با عصاره ى آبى

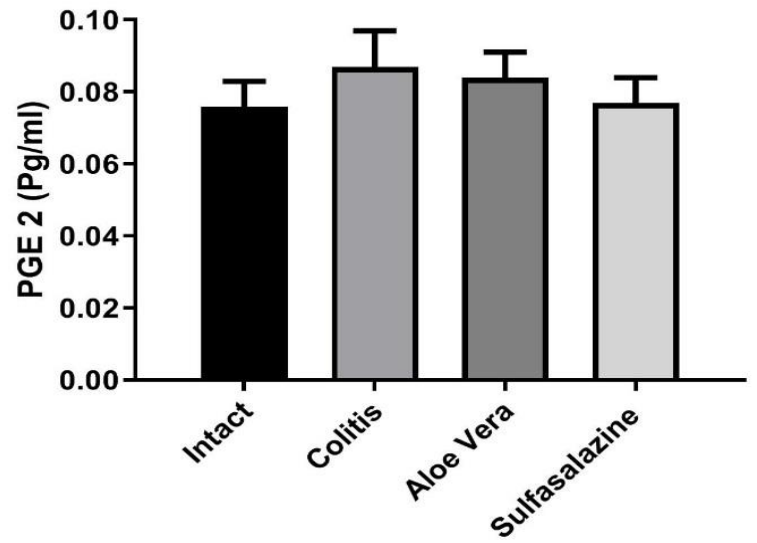

نمودار r: تغييرات غلظت PGE 2 بافتى دركروه هاى مختلف كنترل، كوليت القا شده با اسيد استيك، درمان با آلوئه ورا، درمان با

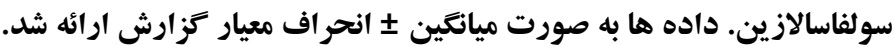




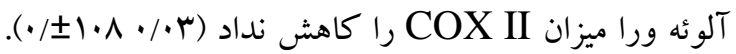

تغييرات سطح فعاليت آنزيم سيكلواكسيزناز دو ( COX

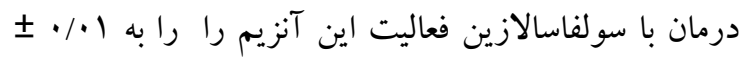

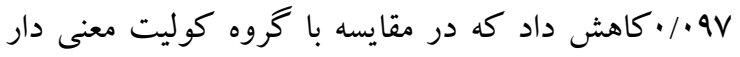
ميزان COX II در گروه سالم r •

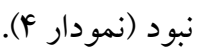

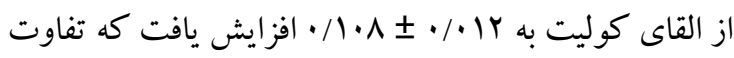

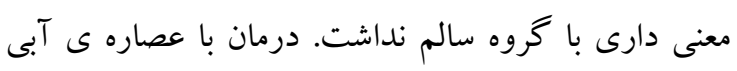

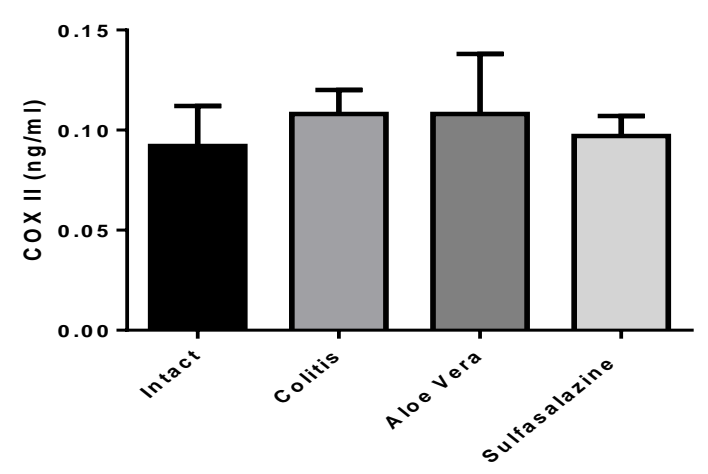

نمودار f. تغيير ات غلظت COX II بافتى دركروه هاى مختلف كنترل، كوليت القا شده با اسيد استيك، درمان با آلوئه ورا، درمان با سولفاسالازين. داده ها به صورت ميانكين ـ انحر داف معيار كز ارش ارائه شد.

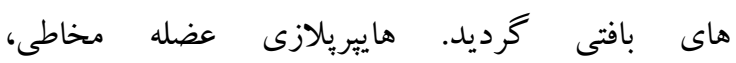
لنفويلاسماسيتوز ، هايبر يلازى سلول هاى اندو كرين و ايجاد

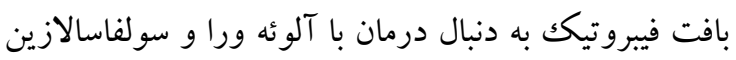

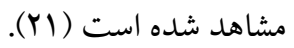

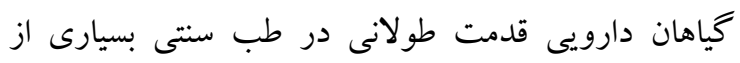

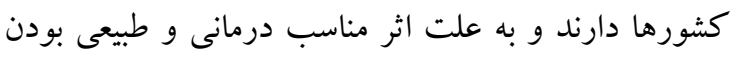

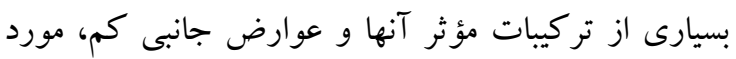

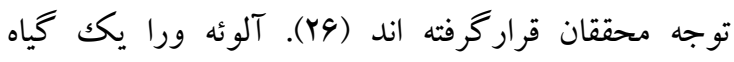

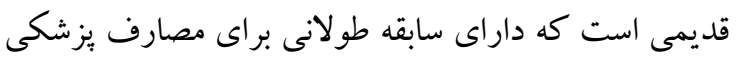
مى باشد، كه مى تواند باعث بهبود عملكرد سيستم ايمنى و

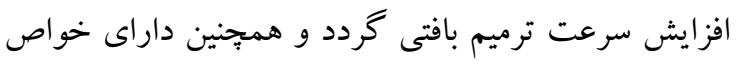

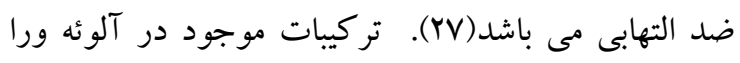

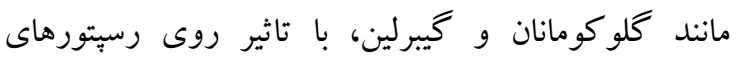

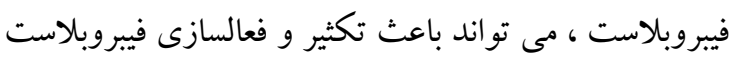

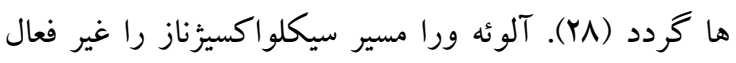

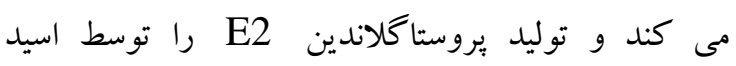

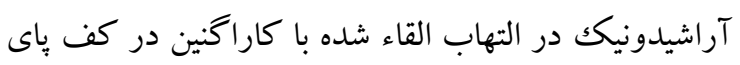

القا كوليت با تزريـق درون ركتومى اسـيد استيكك يكى از

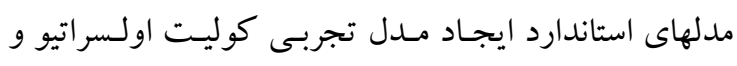

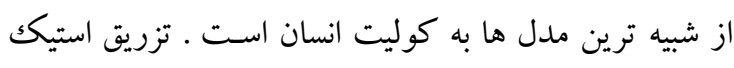

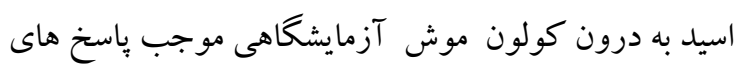

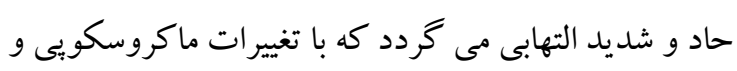

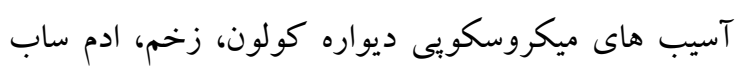

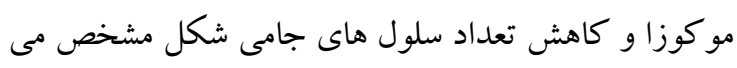

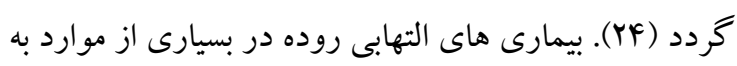

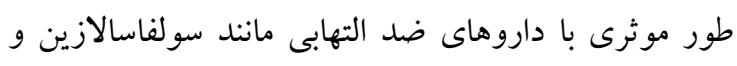

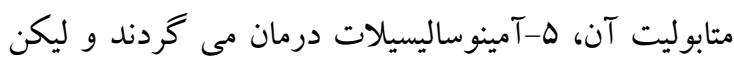

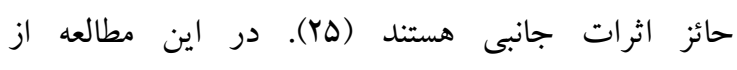
سولفاسالازين به عنوان كنترل مثبت استفاده گرديد. تجويز

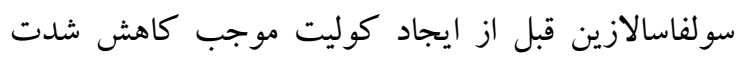
التهاب، آسيب هاى ماكروسكويى و ميكروسكويى كولون كرديد. تجويز آلوئه ورا بعد از ايجاد كوليت مشابه سولفاسالازين موجب كاهش آسيب هاى التهابى و آسيب 
،سايتو كاينى با جنند عملكرد در تنظيم سيستم ايمنى و التهاب است. اين اينترلو كين موجب كاهش بيان سايتو كاين هاى باى لنفوسهيت T كمك كننده يك و بِ بادتنهاى مجموعه ساز كارى بافتى اصلى كلاس دو مى شود. IL-10 همجنين موجب افزايش تكثير و بقاى لنفوسيتهاى B و توليد آنتى دافي

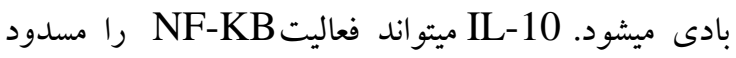
كند (هr). در مطالعه اى كه توسط شوله ور و همكاران صورت گرفت نشان داده شد كه اثرات ضد التهابى آلوئه ورا همراه با كاهش توليد نيتريكك اكسايد است كه منجربه كاهش آزادسازى مدياتورهاى التهابى مانند

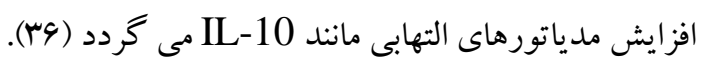
با توجه به مطالعات متعلد صورت گرفته شده توسط آلوئه وراو مشاهده اثرات قابل توجه آلوئه ورا در كاهش التهاب، ادم، نكروز و كاهش بافت آسيب ديده، مى توان نتيجه

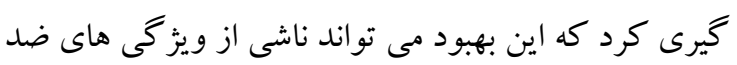

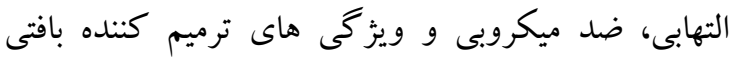
آلوئه ورا باشد (FV-rV). در مطالعه اى كه اثرات ضد التهابى و ضد اولسرى عصارهى آبى -الكلى آلوئه ورا را مورد بررسى قرار دادند مشاهده شد كه عصاره عى آبى آبى -

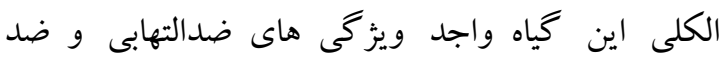
اولسرى در ادم ايجاد شده با فرمالدهيد در كف بِ باى موش صحرايى مى باشد (Fا). در مطالعه ديخرى كه توسط ايملمنام و همكاران صورت گرفت به بررسى اثرات آلوئه وراو سو كرالفات بر سطوح سايتو كين هاى معدى و ترميم

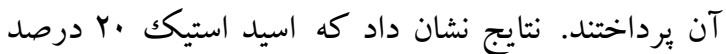
باعث القاى التهاب معدى، افز ايش سطوح كاهش مقادير IL-10 كرديد. وليكن درمان با آلوئه ورا باعث كاهش سطوح TNFو سرعت ترميم اولسر معدى را بيش برد كه تا حدودى با ونا نتايج مطالعه ما هماهنگك بود (Yr).

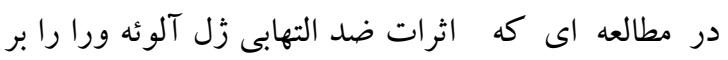
مخاط كولور كتال انسانى مورد بررسى قرار د دادند، مشاهده

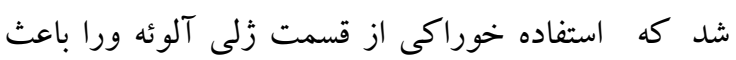

موش صحرايى كاهش مى دهد (YN). برادى كيناز موجود در آلوئه ورا مى تواند برادى كينين كه يك ميانجى التهابى است را كاهش دهد (Yq). همجنين آلوئه ورا باعث كاهش

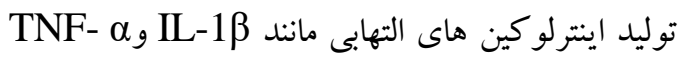
شود و از اين طريق باعث كاهش التهاب مى گرددد (YN).

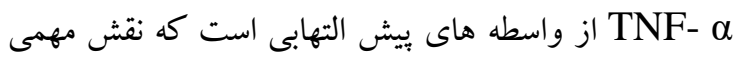

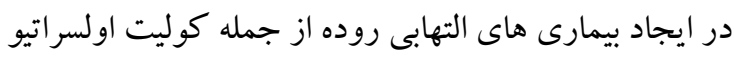

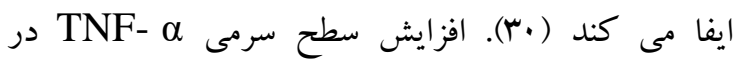
بيماران مبتلا به كوليت اولسراتيو تاييدى بر اين ارتباط است است

توانايى آلوئه ورا در ايجاد اثرات ضد التهابى در طرحى

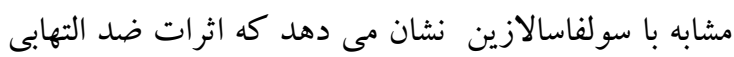

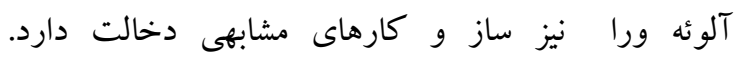

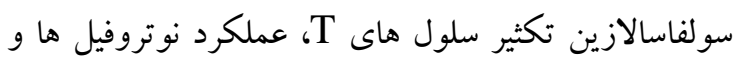
ماكروفازها (Yr)، ترشح بروستا گلندين ها و و

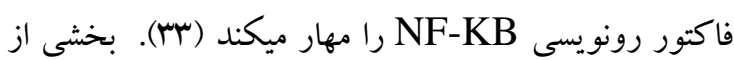
اثرات آلوئه ورا احتمالا مربوط به اثرات ضد التهابى مى مئس باشد. آلوئه ورا فاكتور رونويسى NF-KB را مهار ميكند و

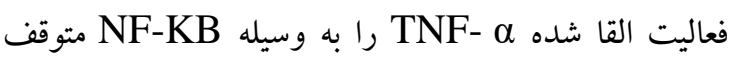

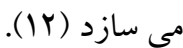
ايترلو كين ها، سايتو كاين هاى ساخته شده توسط انواع گو يجه هاى سفيد خون هستند كه اغلب بر لنفوسيتهاى ديخر مؤثر هستند. اين تركيبات در سيستم ايمنى نقش مهمى دارند

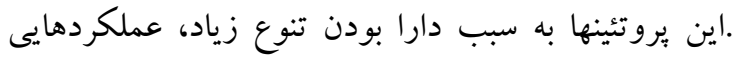

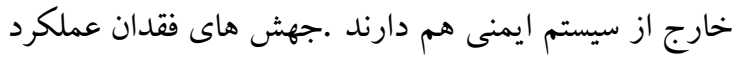
در گيرنده ى IL-10 به كوليت اولسروز شديد، در ارتباط

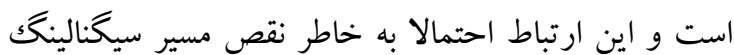
IL-10 سايتو كاين است كه در مهار ياسخهاى التهابى و ايمنى نقش

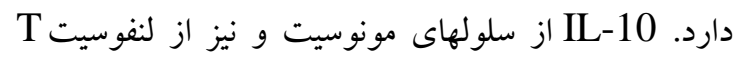
كمك كننده ماكروفاز و لنفوسيت T تنظيم كننده و ماست مون سل ترشح مى شود و بر سلولهاى لنفوسيت T كمكك كننده، كنئ

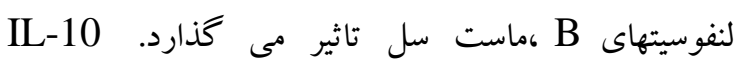




$$
\begin{aligned}
& \text { در بافت كولون گرديد، كه نشانگر اثرات ضد التهابى زل } \\
& \text { آلوئه ورا مى باشد و مى توان از اين گياه به عنوان يكك } \\
& \text { مكمل درمانى در بيمارى التهابى روده استفاده كرد. }
\end{aligned}
$$

$$
\begin{aligned}
& \text { تشكر و قدردانى }
\end{aligned}
$$

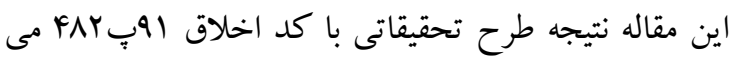

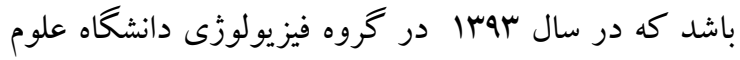

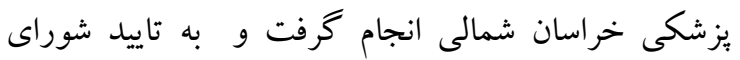

$$
\begin{aligned}
& \text { اخلاق دانشگاه علوم يزشكى خراسان شمالى رسيده است. } \\
& \text { بدينوسيله ازمعاونت تحقيقات و فنـاورى دانشكاه علدوم } \\
& \text { يزشكى خراسان شمالى جهت حمايت مالى اين تحقيق } \\
& \text { تشكر و قدردانى مى شود. }
\end{aligned}
$$

$$
\begin{aligned}
& \text { كاهش التهاب در بيماران با بيمارى التهابى روده مى شود. } \\
& \text { در اين مطالعه ديده شد كه زل آلوئه ورا به صورت وابسته } \\
& \text { به دوز باعث مهار توليد متابوليت هاى واكنشى اكسيزنى }
\end{aligned}
$$

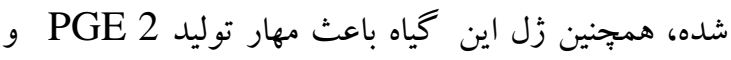

$$
\begin{aligned}
& \text { r.r. كرديد (Fr) IL-8 }
\end{aligned}
$$

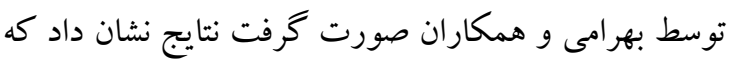

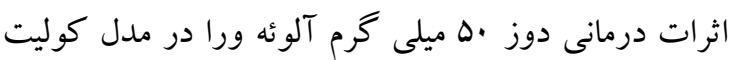

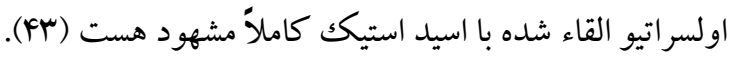

$$
\begin{aligned}
& \text { نتيجه كيرى } \\
& \text { بنابراين با توجه به نتايج كفته شده مشخص كردي كرديد كه } \\
& \text { عصاره آبى زل آلوئه ورا باعث كاهش مقادير فاكتور نكروز } \\
& \text { دهنده تومور آلفاو افزايش فاكتور ضد التهابى اينترلو كين ده ورها }
\end{aligned}
$$

1.Gajendran M, Loganathan P, Jimenez G, Catinella AP, Ng N, Umapathy C, et al. A comprehensive review and update on ulcerative colitis. Dis Mon. 2019;65(12):100851.

2.Marafini I, Sedda S, Dinallo V, Monteleone G. Inflammatory cytokines: from discoveries to therapies in IBD. Expert Opin Biol Ther. 2019;19(11):1207-17.

3.Zhou Q, Shen Z-F, Wu B-s, Xu C-b, He Z-q, Chen T, et al. Risk of Colorectal Cancer in Ulcerative Colitis Patients: A Systematic Review and Meta-Analysis. Gastroenterol res pract. 2019;2019.

4.Chassaing B, Aitken JD, Malleshappa M, Vijay-Kumar M. Dextran sulfate sodium (DSS)-induced colitis in mice. Curr protoc immunol. 2014;104(1):15.25. 1-15.25. 14.

5.Tanideh N, Afaridi E, Mehrabani D, Azarpira N, Hosseinzadeh M, Amini M, et al. The healing effect of Berberis vulgaris in acetic acid-induced ulcerative colitis in rat. Middle East $\mathrm{J}$ Sci Res. 2014;21(8):1288-94.

6.Che C. Plants as a source of apotential anti viral agents. Economic and medicinal plant research. Academic Press. london; 1991.

7.Mehrabani D, Nasibi M, Izadpanah A, Tanideh N, Amini M, Hosseini S. The Comparison of two methods of steroid therapy via appendicostomy and enema in experimental acetic acid induced ulcerative colitis in dog. World Appl Sci J. 2013;26(12):1538-45.

9.Tanideh N, Akbari Baseri F, Jamshidzadeh A, Ashraf M, Kuhi O, Mehrabani D. The healing effect of strawberry extract on acetic acid-induced ulcerative colitis in rat. World Appl Sci J. 2014;31(3):281-8.

10.Tanideh N, Masoumi S, Hosseinzadeh M, Safarpour AR, Erjaee H, Koohi-Hosseinabadi O, et al. Healing effect of pistacia atlantica fruit oil extract in acetic Acid-induced colitis in rats. Iran $\mathrm{j}$ med sci. 2014;39(6):522-8

11.Zargari-Samadnejad A, Mehrvarz S, Allizadeh-Naeini S, Tanideh N. Healing effect of Licorice extract in acetic acid-induced ulcerative colitis in rat. Res Pharma Sci. 2012;7(5):837.

12.Gupta VK, Malhotra S. Pharmacological attribute of Aloe vera: Revalidation through experimental and clinical studies. Ayu. 2012;33(2):193-6.

13.Lee KH, Kim JH, Lim DS, Kim CH. Anti-leukaemic and anti-mutagenic effects of Di (2-ethylhexyl) phthalate isolated from Aloe vera Linne. J Pharm Pharmacol. 2000;52(5):593-8.

14.Asamenew G, Bisrat D, Mazumder A, Asres K. In vitro antimicrobial and antioxidant activities of anthrone and chromone from the latex of Aloe harlana Reynolds. Phyto Res. 2011;25(12):1756-60.

هبلم علدى دانشكاه علوه بِزشكى كردستان / دوره بيست و شش / دعر و آبان م.ع|| 
15.Gomes de Melo J, de Sousa Araújo TA, e Castro TNdA, Lyra de Vasconcelos Cabral D, Do Desterro Rodrigues M, Carneiro do Nascimento S, et al. Antiproliferative activity, antioxidant capacity and tannin content in plants of semi-arid northeastern Brazil. Molecules. 2010;15(12):853442.

16.Akev N, Turkay G, Can A, Gurel A, Yildiz F, Yardibi H, et al. Tumour preventive effect of Aloe vera leaf pulp lectin (Aloctin I) on Ehrlich ascites tumours in mice. Phytother Res. 2007;21(11):10705.

17.De Melo JG, Santos AG, de Amorim ELC, Nascimento SCd, de Albuquerque UP. Medicinal plants used as antitumor agents in Brazil: an ethnobotanical approach. Evid Based Complement Alternat Med. 2011;2011.

18.Liu X, Wang J. Anti-inflammatory effects of iridoid glycosides fraction of Folium syringae leaves on TNBS-induced colitis in rats. J Ethnopharmacol. 2011;133(2):780-7.

19. Veenbergen S, Li P, Raatgeep H, Lindenbergh-Kortleve D, Simons-Oosterhuis Y, Farrel A, et al. IL-10 signaling in dendritic cells controls IL-1 $\beta$-mediated IFN $\gamma$ secretion by human CD4+ T cells: relevance to inflammatory bowel disease. Mucosal immunol. 2019;12(5):1201-11.

20.Dannenberg AJ, Altorki NK, Boyle JO, Dang C, Howe LR, Weksler BB, et al. Cyclo-oxygenase 2: a pharmacological target for the prevention of cancer. lancet oncol. 2001;2(9):544-51.

21.Keshavarzi Z, Alikhani V, Vatanchian M, Tabatabaei Yazdi A, Bibak B, Mohebbati R. Effects of Aloe Vera Gel on Gastric Acid Secretion and Colon Histopathology in Ulcerative Colitis Model induced by Acetic Acid in Rats. J Zanjan Univ Med Sci 2013; 95 (22): 1-11.

22.Eamlamnam K, Patumraj S, Visedopas N, Thong-Ngam D. Effects of Aloe vera and sucralfate on gastric microcirculatory changes, cytokine levels and gastric ulcer healing in rats. World $\mathbf{J}$ Gastroenterol; 2006;12(13):2034-9

23.Hagar HH, El Medany A, El Eter E, Arafa M. Ameliorative effect of pyrrolidinedithiocarbamate on acetic acid-induced colitis in rats. Europ j pharmacol. 2007;554(1):69-77.

24.Elson CO, Sartor RB, Tennyson GS, Riddell RH. Experimental models of inflammatory bowel disease. Gastroenterology. 1995;109(4):1344-67.

25.Garjani A, Davaran S, Rashidi M, Malek N. Protective effects of some azo derivatives of 5aminosalicylic acid and their pegylated prodrugs on acetic acid-induced rat colitis. DARU J Pharmaceutic Sci. 2004;12(1):24-30.

26.Lin K-Y, Uen Y-H. Aloe-emodin, an anthraquinone, in vitro inhibits proliferation and induces apoptosis in human colon carcinoma cells. Oncol letters. 2010;1(3):541-7.

27.Rajeswari R, Umadevi M, Rahale CS, Pushpa R, Selvavenkadesh S, Kumar KS, et al. Aloe vera: the miracle plant its medicinal and traditional uses in India. J Pharmacog Phytochem. 2012;1(4):11824.

28.Tanwar R, Gupta J, Asif S, Panwar R, Heralgi R. Aloe Vera and its uses in Dentistry. Indian J Dent Adv. 2011;3(4):656-8.

29.Sajjad A, Subhani Sajjad S. Aloe vera: An ancient herb for modern dentistry-A literature review. J Dent Surg. 2014;2014.

30.Wang J, Fu YX. Tumor necrosis factor family members and inflammatory bowel disease. Immunol reviews. 2005;204(1):144-55.

31.Sands BE, Kaplan GG. The role of TNF $\alpha$ in ulcerative colitis. J Clin Pharmacol. 2007;47(8):93041.

32.MacDermott RP. Progress in understanding the mechanisms of action of 5-aminosalicylic acid. American J Gastroenterol. 2000;95(12):3343.

33. Collier H, Francis AA, McDonald-Gibson WJ, Saeed S. Inhibition of prostaglandin biosynthesis by sulphasalazine and its metabolites. Prostaglandins. 1976;11(2):219-25.

34.Budak F, Göral G, Heper Y, Y1lmaz E, Aymak F, Baştürk B, et al. IL-10 and IL-6 gene polymorphisms as potential host susceptibility factors in Brucellosis. Cytokine. 2007;38(1):32-6.

35.Naeimi M, Zahmatkesh Roudsari R. Detection of IL-10 gene polymorphisms in patients with ulcerative colitis in Northern Iran. Med Sci J Islamic Azad Univers-. 2019;29(2):141-9. 
36. Sholehvar F, Mehraban D, Yaghmaei P, Vahdati A. The effect of aloe vera gel on viability of dental pulp stem cells. Dent Traumatol. 2016;32:390-6.

37. Sholehvar F, Mehraban D, Yaghmaei P, Vahdati A. The effect of aloe vera gel on viability of dental pulp stem cells. Dent Traumatol. 2016;32:390-6.

38. Hajhashemi V, Ghannadi A, Heidari AH. Antiinflammatory and wound healing activities of Aloe littoralis in rats. Res Pharm Sci. 2012;7:73-8.

39. Coskun S, Gulec EG, Balabanli B, Acarturk F. Effects of epidermal growth factor on lipid peroxidation and nitric oxide levels in oral mucosal ulcer healing A time-course study. Surg Today. 2007;37:570-4.

40. Dehury S, Tripathy J. Effect of Aloe Vera Leaf Extract in Animal Model of Ulcerative colitis. Europ j pharmaceitical med res. 2017;4:346-50.

41.Metowogo K, Agbonon A, Eklu-Gadegbeku K, Aklikokou A, Gbeassor M. Anti-ulcer and antiinflammatory effects of hydroalcohol extract of Aloe buettneri A. Berger (Lilliaceae). Trop $\mathrm{j}$ pharmaceutic res. 2008;7(1):907-12.

42.Langmead L, Feakins RM, Goldthorpe S, Holt H, Tsironi E, De Silva A, et al. Randomized, double-blind, placebo-controlled trial of oral aloe vera gel for active ulcerative colitis. Aliment Pharmacol Ther. 2004;19(7):739-47.

43. Bahrami G, Malekshahi H, Miraghaee S, et al. Protective and Therapeutic Effects of Aloe Vera Gel on Ulcerative Colitis Induced by Acetic Acid in Rats. Clin Nutr Res. 2020;9(3):223-234. 